\title{
The Evaluation of Teaching Practice from the Perspective of Cooperating Teachers
}

\author{
Ambei Moses Chu \\ B.Ed, C.BA, M.Ed, PhD (In View), Faculty of Education, University of Buea, Cameroon, Central Africa
}

\begin{abstract}
Teacher education is the bedrock of the quality of the educational system of every country. For this quality to be realized, it is important to constantly monitor the stages (theoretical, teaching practice, research project) involved in teacher education.

This study sought to investigate the effectiveness of the teaching practice stage of the teacher education programme in the University of Buea from the perspective of cooperating teachers. More specifically, the study sought to determine from the perceptions of cooperating teachers on whether student teachers command a mastery of the subjects they teach. The research methodology used was a survey of the opinions of 194 cooperating teachers selected through the simple random sampling technique. The subjects completed a self-response questionnaire made up of open and closed-ended items. Data analysis was done using the Statistical Package for the Social Sciences to obtain frequencies, simple percentages, mean scores, and standard deviations were used. The results obtained revealed that participants were divided in their opinions ON the objective that guided the study. Based on these findings, recommendations were made to guide relevant practice, policy and research.
\end{abstract}

\section{KEYWORDS: Evaluation, Teaching Practice, Perspective, Cooperating Teachers}

\section{INTRODUCTION}

In all countries and educational systems, teaching practice is an integral part of the initial training of teachers. Cameroon is not an exception. Many schools have been created, first by missionaries and later the government, to train teachers for various levels of education. The University of Buea was created as a consequence of the Higher Education Reforms of 1993. The Faculty of Education is one of its establishments with the following as mission: to prepare educational personnel in order to promote excellence at all levels of schooling, as well as undertake professional training and advanced studies in educational sciences. In addition, it is supposed to conduct and develop appropriate research and carry out outreach activities in line with the three traditional missions of a university which are teaching, research and service in various forms to the community (outreach) (University of Buea Website).

To achieve this mission, the departments of Educational Foundations and Administration, Educational Psychology and Curriculum Studies and Teaching were created. The department of Curriculum Studies and Teaching (CST) has outlined the following specific objectives in its brochure: train development-oriented teachers of quality for secondary grammar schools, teacher training institutions and higher levels of schooling; promote pedagogic excellence at the secondary school level, and carry out outreach activities to improve the teaching and learning process. At the end of the training exercise, it is expected that the student teachers would have appropriate competences in the dimensions of knowledge, skills and professional attitudes.

Each of the departments of the Faculty has a training model that has three main components: coursework, teaching practice or internship and research project. The aim of this study is to evaluate the teaching practice component in the department of Curriculum Studies and Teaching (CST) from the perspective of cooperating teachers especially on the aspect of subject matter mastery.

\section{STATEMENT OF THE PROBLEM}

The preparation of quality teachers should be a key concern of all teacher training institutions in general and the Faculty of Education in particular. This is because the quality of teachers is critical to efforts to create and sustain productive teaching and learning environment. This has been recognized by the government of Cameroon in

Law 98/004 of April 14, 1998. Teachers are described in this law as guarantors of quality education. The practical training in schools gives "would-be teachers" first-hand experience as to what would be required of them in the real world of practice upon graduation. If teachers are expected to perform well in real world situations, then their performance during teaching practice has to be closely monitored and evaluated in order to determine strengths and weaknesses in order to inform policy and practice. The problem that has provoked this study is that this is not regularly done. At the end of each teaching practice session, the views of all stakeholders involved in the process need to be known. Only after this knowledge can more informed actions be taken to improve the education of teachers in general and the improvement of the teaching practice component in particular. Strengthening links with schools and institutions used for the practical training of students is one of the objectives of the Faculty of Education. The problem leading to this study can be stated in the form of three questions as follows: Do student-teachers exhibit desired professional Attitudes? Do they command a mastery of the subjects they teach? Do they demonstrate mastery of the various instructional methods?

\section{Purpose of the Study}

The purpose of this study is to have cooperating teachers evaluate the effectiveness of teaching practice. This can be 
done from many perspectives. But for the purpose of this study, the perceptions of cooperating teachers on the mastery of the content of subjects they teach is critically examined.

\section{Objective of the Study}

To investigate the perceptions of cooperating teachers on the mastery of subjects taught by student teachers.

\section{Research Question}

Do student teachers exhibit a mastery of the subjects they teach?

\section{BACKGROUND TO THE STUDY}

Cameroonian scholars (for example Shu, 2000; Tchombe, 2000, and Tambo, 2003) has traced the developments of formal education in Cameroon, alongside the evolution of efforts to train teachers beginning with Christian missionaries and later joined by the government. Formal education, according to them, was introduced in Cameroon in 1884 by Joseph Merrick of the London-based Baptist Missionary society and later encouraged by other missionaries, such as the Basel Mission, the German Pallotine Missionaries, and the Roman Catholic mission, among others. Their main mission was evangelization. Interest in basic education was considered a strategy to serve this purpose. In 1851, Alfred Saker opened the first seminary for the training of catechists and teachers at Bethel. In 1889, the Basel Mission opened another seminary to train catechists and primary school teachers in Bonaku, Douala and in 1907, the Catholic mission did the same. They opened a seminary in Sasse, Buea. Many churches and schools were later on created by these missionary bodies and seminaries created to train their catechists and primary school teachers. For example, the Sasse seminary trained teachers who will teach children German, Arithmetic, Geography, History and General Sciences. The first government teacher training college was created at Kake, Kumba. It is important to note that the mission seminaries and the government teacher training college in Kake were created to trained primary school teachers. There was a need to train teachers for secondary education, grammar and technical/vocational education. Today, there are many teacher training colleges, especially for the training of primary school teachers.

After independence, the government, in response to the needs for the training of secondary school teachers, created the Ecole Normale Superieure (ENS) in Yaounde for the training of teachers of secondary grammar schools. The ENS later became the first institution of the Federal University of Cameroon later opened in 1962 (presently known as the University of Yaounde I). In 1967, the government opened an annex campus of the E.N.S. in Bambili to train Anglophone secondary school teachers. In 1979, the Advanced School for the Training of Teachers of Technical Education (E.N.S.E.T.) was opened in Douala. In 2007, the government opened the E.N.S. Maroua. All these teacher training institutions have as their main mission the training of quality teachers for the educational system of the nation. Besides specialized institutions created to train secondary school teachers, the government created the Faculty of Education in the University of Buea in 1993, although its graduates are not automatically integrated into the public service as is the case with graduates from the ENS, it is also important to note that these institutions are not able to supply the number of teachers required by the educational system of the nation. As a consequence, there has been heavy reliance on university graduates with first degrees who master knowledge of various disciplines but do not have pedagogical content knowledge or knowledge of the foundations of education.

\section{Contextual Background}

The training of teachers takes place within a rapidly changing context. This section presents contextual variables that are related to this study. It comprises the purpose and objectives of secondary education, its problems and environmental factors that are putting pressure on education at this level and also driving the need to pay greater attention to the preparation of would-be teachers. This study is being carried out within an environment of greater demand for secondary education and the recognition by the government that teachers are critical to the quality of the educational system and its graduates. The importance attached to education is contained in the formal purpose and specific objectives of secondary education in Cameroon.

The mission, purpose and objectives of secondary education are laid down in the Law of orientation of Basic and Secondary Education in Cameroon (Law No. 98/004 of 14 April, 1998).

According to Section 4 of this law, the general purpose of education shall be to train children for their intellectual, physical, civic and moral development and their smooth integration into the society bearing in mind prevailing economic, socio-cultural, political and moral factors. On the basis of the general purpose, Section 5 stipulates that the objectives of education shall be:

$\rightarrow$ Totrain citizens who are firmly rooted in their culture but open to the world and respectful of the general interest and the common will of others;

$\rightarrow$ To inculcate the major universal ethical values which are dignity and honour, honesty and integrity, as well as a sense of discipline into pupils and students;

$>$ To promote family life;

To promote national languages;

$>$ To develop creativity, a sense of initiative and the spirit of enterprise in to learners.

> To cultivate the love of effort and work well done, the quest for excellence and team spirit.

$>$ To provide physical, sport, artistic and cultural training for the child.

$>$ To promote hygiene and health education.

For these objectives to be effectively achieved, quality teachers are needed. More specifically, Section 37:1 of this law describes teachers as guarantors of quality education. The objectives of the educational system and its expectations for teachers can be partly guaranteed if teacher training institutions are of the best possible quality.

The context within which this study is carried out can also be viewed from the current state of the educational system. The Cameroon educational system has made commendable achievements since independence. However, it is still plagued by numerous problems, among them include shortage of teaching staff in general and particularly those of certain subjects like English, French and Mathematics, too many unqualified teachers, poor implementation of legislation dealing with education, lack of a proper education policy, poorly adapted and over loaded programmes and 
poor organization of the school and academic year (Report of the Sector-Wide Approach to Education, 2005: 53).

The shortage of teachers at every level, has led to the employment of unqualified persons, a situation which prevails more in the private sector. At the primary level of education in Cameroon in the 2003/2004 academic year for example, the ratio of pupil/teacher ratio was 52.6 per teacher and there were 51.4 pupils per class. The estimated need to meet up with the shortage in teaching staff is 25000 teachers (Sector Wide Approach/Education, 2005: 53).

In an attempt to seek solutions to the problems that plaque the Cameroon education system, the government, in 1995, organized a National Education Forum. It was aimed at making proposals for the formulation of a new educational policy for Cameroon so that it may evolve a new educational system that would enable it to meet its twenty-first century challenges (Mbella-Mbappe, 1995). The forum was expected to make concrete suggestions that, when implemented would help in solving the many educational problems faced by the country"s educational system in general and the secondary sub-system in particular. Some of the resolutions of the National Forum became the substance of the law of orientation of basic and secondary education (Law No. 98/004 of 14 April 1998). The law lays down the guidelines for basic and secondary education, identifies its purpose and objectives in Section 4 and 5 respectively.

On the aspect of teachers, Section 37 of Law No. 98/004 describes teachers as principal guarantors of quality education. In this capacity, they are entitled, within the limit of the means available to suitable living conditions, as well as to appropriate initial and continuing training. Also, Section 39 of this same law states that teachers shall be bound to teach, educate, provide educational guidance, promote the quest for scientific knowledge, carry out assessment and be of moral rectitude; they shall abide by the instruments in force, in particular, the internal regulations of the establishment where they teach. All of these are in line with increasing calls for good governance, which among other things require people who are competent in what they do.

In addition, global education initiatives are having serious implications on the educational system. For example, the Education for All initiative (EFA) and its Dakar Framework for Action, the Millennium Development Goals and the importance of achieving them, are among the international drivers of the demand for basic education as well as subsequent levels of education. Coupled with these is the fact that the world is increasingly not only becoming a global village, but one in which the economy is knowledge-driven. In addition to reduce global epidemics such as HIV/AIDs requires greater attention to education, especially at the basic and secondary levels. Paying attention to the quality of teachers and schools must be part of a comprehensive strategy to increase Cameroon"s competitiveness within a global economy.

\section{Theoretical Background}

This section briefly examines the main substance of two theories that are considered relevant to this study, systems theory and the theory of teacher-efficacy. The theories are examined in greater detail in chapter two.

\section{A. Systems Theory}

The system theory was developed by Ludwig von Bertanlanffy (1956). It was developed as a reaction to piecemeal approaches of studying organizations, phenomenon and solving problems. According to the theory the analysis of an organization or attempts to solve problems can be approached from a systemic perspective. A system is made up of parts that are interrelated. Each part has certain functions to perform in order to ensure that the whole is maintained at desired levels.

This theory is very relevant to this study because the training of would-be teachers in the Faculty of Education requires many components and many actors. For example, the training of teachers has been broken down into coursework, teaching practice and a research project. Only students who perform well in all three components are considered to have met graduation requirements. Each component or actor has an important contribution to make to ensure the effectiveness of training. Against this backdrop, teaching practice and cooperating teachers constitute important components whose effectiveness is critical to the ability of the Faculty to achieve stated objectives of teacher training.

\section{B. Self -efficacy Theory}

Generally, the aim of teacher education before and during service is to ensure that they are more effective. In other words, good training increases the ability of an individual to carryout assigned tasks in order to achieve desired objectives. Bandura used the concept of efficacy to refer to perceptions of ability by individuals charged with certain responsibilities. Individuals can either perceive that they have the relevant training to do what is expected of them or they can feel that they do not. Teachers who feel that they can teach and make a difference in the lives of all children can be described as having a sense of high efficacy. Such teachers are not likely to give up when they face difficulties and will be the case with teachers who doubt their efficacy vis-à-vis assigned responsibilities. A high sense of teacher efficacy has been associated with higher levels of teacher motivation, commitment and productivity as well as higher levels of student achievement of desired outcomes. The quality of training is related to perceptions of efficacy among teachers.

\section{MASTERY OF SUBJECT MATTER}

To teach all students according to today's standards, teachers need to understand subject matter deeply and flexibly in order to help students create useful cognitive maps, relate one idea to another and address misconceptions. Tchombe (2004) asserts that the subject matter is not constant. It is constantly changing as the structure and ideas of society alter with advances in technology. Teachers need to see how ideas connect across fields and to everyday life. This kind of understanding provides a foundation for pedagogical content knowledge that enables teachers to make ideas accessible to others (Shulman, 1987). A good knowledge of the subject matter by the teacher minimizes a lot of indiscipline that might emerge during lectures. Teachers who have a good knowledge of their subject matter do not dangle much in class.

Still on subject matter knowledge, the teacher is supposed to understand the central concepts, tools of inquiry and structures of the discipline he/she teaches, and create 
learning experiences that make these aspects of subject matter meaningful for students. Stanley K. (1996) asserts that knowledge of subject matter is usually considered an essential attribute for effective teaching and successful learning. The most meaningful and lasting learning occur when individuals construct knowledge. The role of the teacher is to help learners build their own knowledge through acting on materials and engaging in meaningful experiences. To create these experiences, teachers must possess an in depth understanding of major concepts, assumptions, debates, processes of inquiry and ways of knowing that are central to the disciplines they teach. Knowledge of subject matter also implies an understanding of inquiry used in various disciplines. Inquiry training lets students experience the same process scientists actually goes through when attempting to explain puzzling phenomena. Employing methods such as inquiry training in the classroom allow teachers to engage learners in generating knowledge and testing hypothesis according to methods of inquiry and standards of evidence used in the discipline (Fennema and Frank, 1992). Shulman (1986) introduced the phrase "pedagogical content knowledge" and sparked a whole new wave of scholarly articles on teachers' knowledge of their subject matter and the importance of this knowledge for successful teaching. In Shulman's theoretical framework, teachers need to master two types of knowledge: (a) content, also known as "deep" knowledge of the subject itself, and (b) knowledge of the curricular development. Content knowledge encompasses what Bruner (as cited in Shulman, 1992) called the "structure of knowledge"-the theories, principles, and concepts of a particular discipline. Especially important is pedagogical knowledge that deals with the teaching process, including the most useful forms of representing and communicating content and how students" best learn the specific concepts and topics of a subject. "If beginning teachers are to be successful, they must wrestle simultaneously with issues of pedagogical content (or knowledge) as well as general pedagogy (or generic teaching principles)" (Grossman, as cited in Ornstein, Thomas, \& Lesley, 2000, p. 508). Shulman (1986, 1987, and 1992) created a Model of Pedagogical Reasoning, which comprises a cycle of several activities that a teacher should complete for good teaching: comprehension, transformation, instruction, evaluation, reflection, and new comprehension.

\section{Comprehension}

To teach is to first understand purposes, subject matter structures, and ideas within and outside the discipline. Teachers need to understand what they teach and when possible, to understand it in several ways. Comprehension of purpose is very important. Teachers with good mastery of subject matter are more likely to create and nurture interesting and exciting environments for their students, to teach students to believe and respect others, and to contribute to the well-being of their communities, are more likely to give students the opportunity to learn how to inquire and discover new information and more likely to help students develop broader understandings of new information as well as help students develop the skills and values they will need to function in a free and just society (Shulman, 1992)

\section{Transformation}

According to Shulman, the key to distinguishing the knowledge base of teaching lies at the intersection of content and pedagogy in the teacher"s capacity to transform content knowledge into forms that are pedagogically powerful and yet adaptive to the variety of students abilities and backgrounds. Comprehended ideas must be

transformed in some manner if they are to be taught. Transformation, to him, requires some combination or ordering of the following processes: preparation (of the given text material), which includes the process of critical interpretation, and representation of the ideas in the form of new analogies and metaphors. Teachers' knowledge, including the way they speak about teaching, not only includes references to what teachers "should" do, it also includes presenting the material by using figurative language and metaphors (Glatthorn, 1990). In addition, transformation requires the ability to select from among an array of teaching methods and models, adaptation of materials and activities to reflect the characteristics of student learning styles, and tailoring the adaptations to the specific students in the classroom. Glatthorn (1990) has described this as the process of fitting the material to the characteristics of the students. The teacher must consider the relevant aspects of students" ability, gender, language, culture, motivation, or prior knowledge and skills that will affect their responses to different forms of presentations and representations.

\section{Instruction}

This comprises the variety of teaching acts and includes many of the most crucial aspects of pedagogy: management, presentations, interactions, group work, discipline, humour, questioning, and discovery and inquiry instruction.

\section{Evaluation}

Teachers need to think about testing and evaluation as an extension of instruction, not as being separate from the instructional process. The evaluation process includes checking for understanding and misunderstanding during interactive teaching, aswell as testing students" understanding at the end of lessons or units. It also involves evaluating one"s own performance and adjusting to differences in circumstances.

\section{Reflection}

This process includes reviewing, reconstructing, re-enacting, and critically analyzing one"s own teaching abilities and then grouping these reflected explanations into evidence of changes that need to be made to become a better teacher. This is what a teacher does when he or she looks back at the teaching and learning that has occurred: re-constructs, reenacts, and re-captures the events, the emotions, and the accomplishments. Lucas (as cited in Ornstein et al., 2000) argues that reflection is an important part of professional development. All teachers must learn to observe outcomes and determine the reasons for success or failure. Through reflection, teachers focus on their concerns, come to better understand their own teaching behaviour, and help themselves or colleagues improve as teachers. Through reflective practices in a group setting, teachers learn to listen carefully to each other, which also give them insight into their own work (Ornstein et al., 2000)

\section{New Comprehension}

Through acts of teaching that are "reasoned" and "reasonable," the teacher achieves new comprehension of the educational purposes, the subjects taught, the students, and the processes of pedagogy themselves (Brodkey, 1986). 
Students (the teacher"s audience) are another important element for the teacher to consider while using a pedagogical model. A skilful teacher figures out what students know and believe about a topic and how learners are likely to know new ideas. Teaching in ways that connect with students also requires an understanding of differences that may arise from culture, family experiences, developed intelligence and approaches to learning. Teachers need to build a foundation of pedagogical learning knowledge (Grimmet \& Mackinnon, 1992).

To help all students learn, teachers need several kinds of knowledge about learning. They need to think about what it means to learn different kinds of material for different purposes and how to decide which kinds of learning are most necessary in different contexts. Teachers must be able to identify the strengths and weaknesses of different learners and must have the knowledge to work with students who have specific learning disabilities or needs. Teachers need to know about curriculum resources and technologies to connect their students with sources of information and knowledge that allow them to explore ideas, acquire and synthesize information, frame and solve problems. And teachers need to know about collaborationhow to structure interactions among students so that more powerful shared learning can occur; how to collaborate with other teachers; and how to work with parents to learn more about their children and to shape supportive experiences at school and home (Shulman, 1992).

Acquiring this sophisticated knowledge and developing a practice that is different from what teachers themselves experienced as students, requires learning opportunities for teachers that are more powerful than simply reading and talking about new pedagogical ideas (Ball \& Cohen, 1996). Teachers learn best by studying, by doing and reflecting, by collaborating with other teachers, by looking closely at students and their work and by sharing what they see.

This kind of learning cannot occur in college classrooms divorced from practice or in school classrooms divorced from knowledge about how to interpret practice. Good settings for teacher learning-in both colleges and schoolsprovide lots of opportunities for research and inquiry, for trying and testing, for talking about and evaluating the results of learning and teaching. The combination of theory and practice (Miller \& Silvernail, 1994) occurs most productively when questions arise in the context of real students and work in progress and where research and disciplined inquiry are also at hand. Teaching practice is aimed at making the student teachers to gain more practical knowledge in subject matter of their subject areas. Knowledge of the subject matter without knowledge on how to break down the components for students" consumption will be useless. In this light, teachers need to have a knowledge of the various teaching methods in order to break down and help facilitate the accusation of knowledge by learners as discussed below.

\section{METHODOLOGY}

The purpose of this study is to have cooperating teachers evaluate the teaching practice component of the programme for the training of student-teachers in the Faculty of Education, University of Buea Cameroon, Central Africa .

\section{Research Design}

A research design refers to the overall plan for collecting data in order to answer the research questions (Fraenkle \& Norman 2000). The survey research design is used in this study. Surveys inquire about the feelings, preferences, motivations, attitudes, accomplishments and experiences of a group of people or individuals (Amin, 2005). The survey research design requires data to be collected from subjects using questionnaire or interview guide. This study collected needed data using a questionnaire, designed for cooperating teachers.

\section{Population of the Study}

According to statistics from the Department of Curriculum Studies and Teaching of the Faculty of Education - University of Buea, teaching practice exercise is conducted in 15 secondary schools in Buea Sub-division.

Also, according to the statistics from the Regional Delegation of Secondary Education for the South West RegionCameroon, there are 782 teachers in all the Secondary Schools in Buea Sub-division where University of Buea student-teachers carry out teaching practice. Table 1 below presents the number of teachers per school where teaching practice is done.

Table 1: The distribution of teachers per cooperating school

\begin{tabular}{|c|l|c|}
\hline S/N & \multicolumn{1}{|c|}{ Names of Schools } & No. of Teachers \\
\hline 1 & Bilingual Grammar School Molyko & 174 \\
\hline 2 & Government Bilingual High School Muea & 106 \\
\hline 3 & Government High School Bokova & 33 \\
\hline 4 & Government High School Bokwango & 104 \\
\hline 5 & Government Secondary School Bolifamba - Mile 16 & 19 \\
\hline 6 & Government Secondary School Bomaka & 27 \\
\hline 7 & Government Secondary School Buea Town & 37 \\
\hline 8 & Government Secondary School Great Soppo & 22 \\
\hline 9 & Government Secondary School Tole & 29 \\
\hline 10 & Government Secondary School Wokeka & 1 \\
\hline 11 & Baptist High School Buea & 39 \\
\hline 12 & Jules Peeter"s Memorial College Bokwango & 15 \\
\hline 13 & Presbyterian Comprehensive Secondary School Buea Town & 62 \\
\hline 14 & St. Joseph"s College Sasse & 62 \\
\hline 15 & Our Lady of Mount Camel Muea & 52 \\
\hline \multicolumn{2}{c}{ Total } & $\mathbf{7 8 2}$ \\
\hline
\end{tabular}

Source: Adapted from the statistics of the Regional Delegation of Secondary Education for the South West Region (2010). 
Since each teacher in the cooperating schools is likely to be a cooperating teacher in his or her own field of teaching, the population of the study therefore was approximately 782 teachers.

\section{Sample and Sampling Technique}

Out of a population of 782 cooperating teachers, 200 or $25.6 \%$ were included in the study. Two sampling techniques were used to select the sample, purposive and simple random sampling techniques. Purposive sampling was used to select the schools and simple random sampling to select cooperating teachers. Only teachers in schools in which student-teachers carry out teaching practice were involved in the study. The sample of teachers was selected by using the simple random sampling technique. Table 3.2 below reveals the population and sample selected from each of the schools.

Table 2: Population and sample from each school

\begin{tabular}{|c|l|c|c|}
\hline \multicolumn{1}{|c|}{ S/N Names of Schools } & \multicolumn{1}{c|}{ Population of teachers } & Sample \\
\hline 1 & Bilingual Grammar School Molyko & 174 & 45 \\
\hline 2 & Government Bilingual High School Muea & 106 & 27 \\
\hline 3 & Government High School Bokova & 33 & 8 \\
\hline 4 & Government High School Bokwango & 104 & 27 \\
\hline 5 & Government Secondary School Bolifamba & 19 & 5 \\
\hline 6 & Government Secondary School Bomaka & 27 & 7 \\
\hline 7 & Government Secondary School Buea Town & 37 & 9 \\
\hline 8 & Government Secondary School Great Soppo & 22 & 6 \\
\hline 9 & Government Secondary School Tole & 1 & 7 \\
\hline 10 & Government Secondary School Wokeka & 29 & 0 \\
\hline 11 & Baptist High School Buea & 39 & 10 \\
\hline 12 & Jules Peeter"s Memorial College Bokwango & 15 & 4 \\
\hline 13 & Presbyterian Comprehensive Secondary School Buea Town & 62 & 16 \\
\hline 14 & St. Joseph"s College Sasse & 62 & 16 \\
\hline 15 & Our Lady of Mount Camel Muea & 52 & $\mathbf{2 0 0}$ \\
\hline & & $\mathbf{7 8 2}$ & \\
\hline
\end{tabular}

\section{Instrumentation}

Data collection for this study was done using a questionnaire.

$$
\text { Development: }
$$

Items for the questionnaire were derived from the review of related literature.

\section{Validity and Reliability}

After constructing the questionnaire, some copies were distributed to some of the investigator"s classmates for peer review. They were asked to critically evaluate the questionnaire in terms of its appropriateness to the research questions and clarity of the instructions and items. Also, the supervisor of the study also examined the instrument to be sure that it could be used to collect relevant data. Feedback from peers and supervisor were used to revise the items. At the end of revision of the items, the questionnaire was later presented to the supervisor of the thesis who confirmed it to be valid. To ensure that the instrument was reliable, it was administered to 30 cooperating teachers who were not included in the study. In addition, the researcher ensured that the language used was very simple.

\section{Ethical Considerations}

A cover letter to the respondents containing the name of the researcher, the topic under investigation, and the purpose of the investigation accompanied the questionnaire. The letter also contained an appeal to the respondents to complete the questionnaire, with guarantee of confidentiality of the responses, and that participation was voluntary and could be withdrawn without consequences. The subjects were told not to write their names on the questionnaire.

\section{Data Collection}

Data collection was done after receiving the supervisor's approval. The researcher visited the principals of the schools under investigation and sought their permission to administer the questionnaire to cooperating teachers. With the permission of the principals, the researcher met the cooperating teachers selected for the study on individual basis and appealed to them to respond to the questionnaire. With the approval of the subjects, the questionnaire was then administered to them with the assistance of the research assistants who had earlier received instruction for a few hours on the administration of the questionnaire. After the exercise, 194 (97\%) copies of the distributed questionnaire were collected.

\section{FINDINGS}

Ten structured questionnaire items were constructed to answer this research question. The respondents were required to tick one of the four response options provided for each item. Options included strongly agree, Agree, Disagree, and, strongly disagree, For the purpose of data analysis, the frequencies and percentages of the strongly agree and agree responses as well as the disagree and strongly disagree responses have been combined and presented in table 3 below. 
International Journal of Trend in Scientific Research and Development (IJTSRD) @ www.ijtsrd.com eISSN: 2456-6470

Table 3: Frequencies and percentages of combined positive and negative responses

\begin{tabular}{|c|c|c|c|c|c|c|}
\hline \multirow{2}{*}{ Item } & \multirow{2}{*}{ Statement } & \multicolumn{2}{|c|}{ SA/A } & \multicolumn{2}{|c|}{ D/SD } & \multirow{2}{*}{$\begin{array}{l}\text { Sample } \\
\text { size }\end{array}$} \\
\hline & & f & $\%$ & f & $\%$ & \\
\hline 1. & Student teachers are knowledgeable in their subject areas & 188 & 96.91 & 6 & 3.09 & 194 \\
\hline 2. & $\begin{array}{l}\text { Student teachers are able to connect ideas across fields of } \\
\text { study and relate them to every day"s life. }\end{array}$ & 44 & 22.68 & 150 & 77.32 & 194 \\
\hline 3. & Student teachers are current in their knowledge domains. & 184 & 94.85 & 10 & 5.15 & 194 \\
\hline 4. & $\begin{array}{l}\text { Student teachers demonstrate love for teaching their } \\
\text { subjects. }\end{array}$ & 182 & 93.81 & 12 & 6.19 & 194 \\
\hline 5. & Student teachers dangle much during his/her lessons. & 183 & 94.33 & 11 & 5.67 & 194 \\
\hline 6. & $\begin{array}{l}\text { Student teachers are able to present good structures of } \\
\text { their disciplines and captures students" interests. }\end{array}$ & 149 & 78.84 & 40 & 21.16 & 194 \\
\hline 7. & $\begin{array}{l}\text { Student teachers have abilities to present content in both } \\
\text { oral and written forms. }\end{array}$ & 187 & 96.39 & 7 & 3.61 & 194 \\
\hline 8. & $\begin{array}{l}\text { Student teachers encourage students" to ask questions } \\
\text { and he gives appropriate answers. }\end{array}$ & 39 & 20.10 & 155 & 79.9 & 194 \\
\hline 9. & $\begin{array}{l}\text { Student teachers demonstrate the ability to evaluate } \\
\text { student understanding of lessons contents. }\end{array}$ & 47 & 24.23 & 147 & 75.77 & 194 \\
\hline 10. & $\begin{array}{l}\text { Student teachers engage students in knowledge } \\
\text { generative activities. }\end{array}$ & 4 & 2.06 & 190 & 97.94 & 194 \\
\hline
\end{tabular}

The results of the data analysis done in Table 3 above shows that there are divisions across the ten items set to answer this research question. The combined frequencies and percentages of the strongly agree and agree responses range from 4 (2.06\%) to $188(96.91 \%)$ while that of the disagree and strongly disagree responses is from $6(3.09 \%)$ to 190 (97.94\%). Of the ten items five reveals strong agreement while the other five reveal strong disagreement. For example, asked to say whether student teachers are knowledgeable in their subject areas, 188 (96.91\%) either strongly agreed or simply agreed. On the other hand, $147(75.77 \%)$ are not of the opinion that student teachers demonstrate the ability to evaluate student understanding of what is taught. Also, while 184 (94.85\%) of the subjects think that student teachers are current in their knowledge domains, 190 $(97.94 \%)$ think student teachers do not engage students in knowledge generative activities.

In Table 4 below, the mean scores and standard deviations of all the ten items designed to answer this research question tare presented. A cut-off mean of 3.00 will be used to interpret the results. That is, an item with a mean of 3.00 or above reveals that student teachers are positive in the domain described in the item.

Table 4: The means and standard deviations (SD) for all questionnaire items for research question two.

\begin{tabular}{|c|l|c|c|}
\hline No. & \multicolumn{1}{|c|}{ Statement } & Mean & SD \\
\hline 1. & Student teachers dangle much during his/her lessons. & 3.45 & 0.68 \\
\hline 2. & Student teachers are knowledgeable in their subject areas & 3.40 & 0.55 \\
\hline 3. & Student teachers demonstrate love for teaching their subjects in the classroom & 3.29 & 0.57 \\
\hline 4. & Student teachers are current in their knowledge domains. & 3.28 & 0.4 \\
\hline 5. & Student teachers have abilities to present content in both oral and written forms. & 3.24 & 0.50 \\
\hline 6. & $\begin{array}{l}\text { Student teachers are able to present good structures of their disciplines and capture } \\
\text { students" interests. }\end{array}$ & 3.01 & 0.78 \\
\hline 7. & $\begin{array}{l}\text { Student teachers demonstrate the ability to evaluate student understanding of } \\
\text { lesson contents. }\end{array}$ & 2.03 & 0.79 \\
\hline 8. & $\begin{array}{l}\text { Student teachers are able to connect ideas across fields of study and relate them to } \\
\text { everyday life. }\end{array}$ & 2.02 & 0.85 \\
\hline 9. & Student teachers encourage students" questions and give appropriate answers. & 1.92 & 0.69 \\
\hline 10. & Student teachers engage students in knowledge generative activities. & 1.55 & 0.61 \\
\hline
\end{tabular}

Table 4 present means scores ranging from $1.55-3.45$. The results are mixed. Of the ten items six including one with a negative opinion statement have means above the cut-off point of 3.00 and four have means below. By implication, cooperating teachers are divided in their opinions as to whether student teachers command a mastery of the subjects they teach.
Mixed perception of the subjects suggests that student teachers are on the average in terms of command of mastery of the subject they teach. This situation needs to be improved upon because to teach all students according to today's standards, teachers need to understand subject matter deeply and flexibly so they can help students create useful cognitive maps, relate one idea to another, and address misconceptions. This is supported by Lockheed 
(1989) who argues that effective teaching is determined by the teacher's knowledge of the subject matter. To him, evidence from developed countries shows that the teacher"s knowledge of the subject matter has a strong positive effect on students" achievement. Harbison and Hanushek (1992) also asset that teachers who know their subject matter perform better than those who do not. Shulman (1987) believes that to improve on the academic performance of students, teachers must comprehend both the subject and pedagogic skills such as asking good questions and evaluation of students. This will enhance students" achievement. Shulman further states that a teacher with basic pedagogical skills understands the subject for his or herself and is able to explain that knowledge in a new way using examples and demonstrations so that it can be grasped by students. Students taught by such a teacher will definitely perform very well in an examenation. But if a teacher is wanting in pedagogical skills, his students will hardly perform well. Luma (1989) supports this argument when she said teachers are giver of knowledge and can " $t$ give the knowledge if they don"t have it. Stanley K. (1996) asserts that knowledge of subject matter is usually considered an essential attribute for effective teaching and successful learning.

Shulman recommended in his 1992 theoretical framework that teachers need to master two types of knowledge: content, also known as "deep" knowledge of the subject itself; and knowledge of the curricular development. Content knowledge encompasses what Bruner (as cited in Shulman 1992) called the "structure of knowledge"-the theories, principles, and concepts of a particular discipline. Especially important is content knowledge that deals with the teaching process, including the most useful forms of representing and communicating content and how students" best learn the specific concepts and topics of a subject.

The student teacher as does a professional is supposed to understand the central concepts, tools of inquiry and structures of the discipline he/she teaches, and create learning experiences that make these aspects of subject matter meaningful for students. "If beginning teachers are to be successful, they must wrestle simultaneously with issues of pedagogical content (or knowledge) as well as general pedagogy (or generic teaching principles)" (Grossman, as cited in Ornstein, Thomas, \& Lasley, 2000, p. 508). The responsibility to improve student teachers" knowledge of their subject contents to a large extent rest on the Faculty of education. To successfully achieve this would require that the Faculty assign more courses on the time table that focus on the subject area of the students. Also subject area course evaluation formalities should be adjusted in a way that would strengthen student teachers commitment towards their subject area.

\section{Conclusion}

Education is the top priority of the Cameroon nation according to Section 2 of Law No. 98/004 of 14 April 1998 to lay down guidelines for basic and secondary education in Cameroon. But the teacher is the principal guarantor of quality education according to Section 37 of the same law. The Faculty of Education over the years has been committing time and resources to train quality teachers through programs encompassing course work and teaching practice. This study has empirically investigated the perceptions of cooperating teachers concerning the effectiveness of teaching practice in the domains of student teachers" professional attitudes, knowledge of subject matter and ability to use different teaching methods. Data analysis for the three research questions set to guide the study revealed that cooperating teachers are divided in their opinions as to whether teaching practice is effective; thus inconclusive results, although much efforts has been made, improving the quality of teacher training in the University of Buea constitutes an important challenge to the Faculty of Education, the cooperating schools involved and the student teachers themselves; in a framework of shared commitment.

\section{Recommendations}

The following recommendations are made based on the findings of this study to the Faculty of Education, cooperating teachers and student teachers.

\section{To the Faculty of Education}

$>$ The Faculty of Education could assign more courses on the time table that focus on the subject area of the students. In the same light, the work scheme per such course should be widened and deepened with associated lesson hours expanded. This would equip the student teachers with a wide and deep knowledge of the subject area.

Both broad and deep course evaluation methods should be enforced and the criteria for a pass in courses of the subject area be strictly respected. This would strengthen student teachers commitment towards their subject area.

The Faculty of Education should strengthen their relationship with cooperating

schools; especially cooperating teachers as the researcher realized in the field that the existing relationship was not better. For example cooperating teachers are disgruntle of the late and sometimes no compensation for their services. This could be a potential reason for the ineffectiveness of the teaching practice exercise.

The distribution of student teachers for teaching practice should take in to

consideration students" residence and preferences. Students could be privileged to present three choices of schools where they wish to carry out teaching practice. They can therefore be distributed according to their first, second or third choice; but where no choice is feasible, they can be sent to a school at the closest possible range. This helps to reduce inconveniences like cost of transportation and lateness while ensuring greater focus on the teaching practice exercise,

$>$ The Faculty of Education should organize seminars at least twice per teaching practice session that focus on teaching practice expectations such as strict respect of professional ethics, dynamism and creativity. Student teachers should be constantly reminded of their professional expectations and the implication it would have on their profession. This would raise the level of awareness and help ensure professionalism.

$>$ It is largely impossible for an individual to engage seriously in less motivating and unprofitable study. Student teachers receive training, become professionals, graduate from school and stay unemployed. The Faculty of education could carry on negotiations with the government that would integrate the best graduating students into the public service. This would act as a motivator for effective teaching practice. 
$>$ It is important for the Faculty of Education to communicate to its newly admitted students the goals and objectives of the Faculty so as to give the students a clear focus on their individual careers.

\section{To cooperating schools and teachers}

$>$ Cooperating schools should place student teachers only under teachers that have received formal training and graduated from a teacher training institution with at least three years of professional experience.

$>$ Student teachers should be given multiple task in the class room that will need the diversity of teaching methods

$>$ Cooperating teachers should be welcoming and communicate love to student teachers. They should have a sense of pride and demonstrate love for the teaching profession. This would create a sense of admiration in the student teachers for the teaching profession and help them take teaching practice seriously.

\section{To student teachers}

$>$ Student teachers should develop self-efficacy toward their chosen careers.

$>$ Theoretical knowledge is a key to practice. In this light, student teachers need to pay serious attention toward course work if they must be effective and efficient in the field.

\section{REFERENCES}

[1] America. (2001). American Evaluation Association.

[2] Amin, M.E. (2005). Social science research. Conception, methodology and analyses. Makerere University Printery, Kampala.

[3] Anja, S.N. (2006).Management, teaching practice and principles made easy. Paron Publishing House.

[4] Bandura, A. (1977). Self-efficacy toward a unifying theory of behavioural change. Psychological Review, 198-215.

[5] Brodkey, J.J. (1986). Learning while teaching. Unpublished doctoral dissertation, Stanford University.

[6] Cameroon. (1995).National Forum on Education. Final Report, Yaoundé.

[7] Cameroon. (2005). Draft Document of the Sector Wide Approach / Education.

[8] Darling-Hammond, L. (1994, September). Will 21stcentury schools really be different? The Education Digest, 60, 4-8.

[9] Fonkeng E.G .(2006)The history of education in Cameroon 1884-2004

[10] Glatthorn, A. A. (1990). Supervisory leadership. New York: Harper Collins.

[11] Grimmet, P., \& MacKinnon, A. (1992). Craft knowledge and the education of teachers. In G. Grant (Ed.), Review of research in education 18, pp. 59-74 Washington, DC: AERA.
[12] Law number 98/004 of $14^{\text {th }}$ Ariel 1998 ,to lay down guidelines for primary and secondary education in Cameroon

[13] Lockheed, M.E. \& Andre Koneman (1989). Teaching qualities and school effects on student achievement in Africa. The case of Nigeria and Swaziland: Edu 5. No. 30.

[14] Luma, E. L. (1983). The education of African teachers. Yaoundé: SOPECAM Inc.

[15] Mac0jong T.T. (2008). Philosophical and historical foundation of education in Cameroon 1884- 1960. University of Buea. Design House, Limbe Makereke University printing, Kampala

[16] Mbua, F. N. Educational administration (2003). Theory and practice. The management of organizations and individuals. University of Buea. pressprint Ltd, Limbe

[17] Miller, L., \& Silvernail, D. L. (1994). Wells Junior High School: Evolution of a professional development school. In L. Darling-Hammond (Ed.), Professional development schools: Schools for developing a profession(pp.56-80). New York: Teachers College Press.

[18] Ornstein, A. C., Thomas, J., \& Lasley, I. (2000). Strategies for effective teaching. New York: McGrawHill.

[19] Robert M.J(2006) Journal of Agricultural Education Volume $47(3)$ p.9

[20] Shamrock, J. W (2004) Educational psychology. University of Texas at Dallas McGraw-Hill

[21] Shulman, L. (1992, September-October). Ways of seeing, ways of knowing, ways of teaching, ways of learning about teaching. Journal of Curriculum Studies, 28, 393-396

[22] Shulman, L. (1986). Those who understand: Knowledge growth in teaching. Educational Researcher, 15 (2), 414.

[23] Shulman, L. (1987). Knowledge and teaching: Foundations of the new reform. Harvard Educational Review, 57 (1), 1-22. Ball, D. L., \& Cohen, D. K. (1996). Reform by the book: What is--or might be--the role of curriculum materials in teacher learning and instructional reform? Educational Researcher, 25(9), 68.

[24] Tambo (2003).principles and methods of teaching. Application in Cameroon schools. University of Buea Pressprint, Limbe

[25] Tambo, I.L. (2003).Cameroon National Education Policy since the 1995 Forum. University of Buea: Design House, Limbe.

[26] Tchombe T.M.(2004). Psychological parameters in teaching .Yaoundé. ISBN University of Buea Website 